Check for updates

Cite this: RSC Adv., 2017, 7, 41610

Received 6th July 2017

Accepted 22nd August 2017

DOI: $10.1039 / c 7 r a 07444 a$

rsc.li/rsc-advances

\section{Physical, antioxidant and antimicrobial properties of modified peanut protein isolate based films incorporating thymol}

\author{
Tianchen Zhong, (D) Yue Liang, Shan Jiang, Lulu Yang, Yimo Shi, Siwen Guo \\ and Chunhong Zhang*
}

An active film made from modified peanut protein isolate (PPI) and incorporating thymol (TML) was developed. The physical, antioxidant and antimicrobial properties of modified PPI based films containing TML at $0.5,1,1.5$, and $2 \%(w / v)$ were examined. Incorporation of TML decreased the water vapor permeability, tensile strength (TS) and percentage of elongation at break (E) of the film. TML incorporation decreased the transparency and made the film darker, but increased the total phenolic content and antioxidant capacity. Antimicrobial activity was significantly increased by adding TML; Staphylococcus aureus and Lactobacillus plantarum were more susceptible than Escherichia coli and Pseudomonas aeruginosa. These results suggest that edible, modified PPI films incorporating an appropriate amount of TML have the potential to preserve food products, which offers a way to use PPI in active food packaging.

\section{Introduction}

As environmental pollution issues caused by non-biodegradable plastic material receive increasing attention, edible and biodegradable films come to the fore. This type of packaging reduces the use of synthetic materials, and has the potential to extend shelf-life and enhance the quality of food. ${ }^{1}$ Edible and biodegradable packaging materials are usually based on proteins, polysaccharides and liquids, or a combination of these, which are natural and sustainable. ${ }^{2}$

Proteins play an important role in film-forming agents due to their superior physical and mechanical properties, as well as their nutritional value. ${ }^{3,4}$ Peanut is an important oil crop in the US and worldwide. Peanut meal is an under-used, low-priced byproduct of the peanut oil industry, and is primarily used for animal feed. ${ }^{5}$ Peanut protein isolate (PPI), extracted from peanut meal, has a higher protein content and better functional properties than other peanut protein products, which could be used to develop films. ${ }^{6}$ However, because of their significant hydrophilicity and poor mechanical properties compared with synthetic films, the properties of peanut protein films must be improved. Chemical, physical and enzymatic treatments of proteins and addition of plasticizers are methods that have been widely and successfully used to improve the mechanical properties of protein films. ${ }^{7}$

Because of the requirements of consumers regarding the quality, safety and preservative-free nature of food, active

College of Food, Shenyang Agricultural University, No. 120 Dongling Road, Shenhe District, Shenyang City 110866, China. E-mail: zhangchsy@163.com; Tel: +86 13840404132 compounds, like antioxidants and/or antimicrobial agents, have been added to edible and biodegradable films..$^{8-11}$ Some studies have demonstrated that some essential oils and their components, which are extracted from various aromatic plants, have strong antioxidant and antimicrobial properties. ${ }^{12-14}$ Therefore, they have been incorporated into edible films to act against foodborne pathogens and increase the shelf-life of food. Thymol (TML), which is a major component of essential oils from oregano and thyme, has shown wide-spectrum antimicrobial activity against Gram-negative and Gram-positive bacteria, as well as fungi. ${ }^{15,16} \mathrm{TML}$ is classified as GRAS (generally recognized as safe), and it is used as a safe food additive in the United States and Europe. ${ }^{17}$ TML was successfully added into chitosan/ polyethylene, polylactic acid, zein nanofibers and polypropylene to make antimicrobial and antioxidant films. ${ }^{18-21}$

Increasing research has been undertaken into edible antimicrobial films based on soy protein, chitosan and zein..$^{22-24}$ However, few edible antimicrobial films based on PPI have been developed. This work was undertaken to optimize the constituents of PPI film using transglutaminase (TG) for improvement of its mechanical properties. The study also aimed to evaluate the physical, mechanical, antioxidant, and antimicrobial properties of modified PPI films containing different concentrations of TML.

\section{Material and methods}

\subsection{Materials}

Defatted peanut meals were provided by Qingdao longevity food Co., Ltd (Shandong, China). Thymol (99.5\%), 2,2-diphenyl-1picrylhydrazyl (DPPH) radical, polyoxyethylene sorbitan mono- 
oleate (Tween 80), glycerol were obtained from Sigma-Aldrich (St. Louis, MO, USA). Transglutaminase (TG), $3713 \mathrm{U} \mathrm{g}^{-1}$ powder, was provided by Dongsheng Food Technology Co., Ltd. (Taizhou, China). The other reagents were purchased from Sinopharm Chemical Reagent Co., Ltd., China.

\subsection{Preparation of peanut protein isolate (PPI)}

PPI was prepared from the defatted peanut meal according to the method of Liu et al. ${ }^{25}$ with slight modifications. Defatted peanut meal was totally dispersed in a 10 -fold volume of deionized water, and the $\mathrm{pH}$ was adjusted to 9.0 with $1 \mathrm{~N} \mathrm{NaOH}$, and stirred at $65{ }^{\circ} \mathrm{C}$ in a water bath for $30 \mathrm{~min}$, then centrifuged in a CR21G high-speed centrifuge (Hitachi Co., Japan) at $8000 \times g$ for $20 \mathrm{~min}$ to remove the insoluble material. The supernatants were acidified to $\mathrm{pH} 4.5$ with $1 \mathrm{~N} \mathrm{HCl}$ and centrifuged at $8000 \times g$ for $10 \mathrm{~min}$. The precipitates were rewashed until $\mathrm{pH}$ was adjusted to 7.0 , and then freeze-dried to obtain PPI.

\subsection{Preparation of modified PPI}

$8 \%(\mathrm{w} / \mathrm{v})$ PPI solution was dispersed in distilled water, the $\mathrm{pH}$ was adjusted to 9.0 and then the solution was heated to $70{ }^{\circ} \mathrm{C}$ for $60 \mathrm{~min}$. After cooling down to room temperature, TG was added to the solution at a ratio of $5 \mathrm{U} \mathrm{g}^{-1}$ of protein. Then the mixture solution was thoroughly stirred for $30 \mathrm{~min}$ in a thermostatic water bath at $50{ }^{\circ} \mathrm{C}$. After that, the reaction was stopped by placing the solution in a water bath at $85{ }^{\circ} \mathrm{C}$ for $20 \mathrm{~min}$, and then cooled to $30-40^{\circ} \mathrm{C}$ to obtain the modified PPI.

\subsection{Preparation of edible films}

Film solution was prepared by casting. Glycerol was added as a plasticizer at $15 \%$ of the protein. Then, tween 80 at $0.2 \%(\mathrm{v} / \mathrm{v})$ was added as an emulsifier to assist TML dissolution. After that, thymol (TML) was separately added to the solution at various concentrations of $0 \%$ (control), $0.5 \%, 1 \%, 1.5 \%$ and $2 \%(\mathrm{w} / \mathrm{v})$ while homogenized (IKA, T25 basic, Germany) at $13000 \mathrm{rpm}$ for $5 \mathrm{~min}$ to obtain emulsions. The film-forming solutions were degassed under vacuum for $10 \mathrm{~min}$ to remove air bubbles. The final film-forming solutions were poured in framed square glass plates $\left(15 \times 15 \mathrm{~cm}^{2}\right)$ and dried at $65{ }^{\circ} \mathrm{C}$ for $3 \mathrm{~h}$. The dried films were peeled off and conditioned in a ventilated climatic chamber (KBF 240 Binder, ODIL, France) at $25{ }^{\circ} \mathrm{C}$ and $55 \%$ relative humidity before testing. Thicknesses of films were measured with a digital micrometer (no. 293-5, Mitutoyo, Japan) and the average was taken $120 \pm 5 \mu \mathrm{m}$.

\subsection{Film analysis}

2.5.1 Mechanical properties. Tensile strength (TS) and elongation at break $(E)$ of films were determined based on ASTM standard D882-97 using an Instron Universal Testing Machine (Instron model 5569, MA, USA) with a $0.5 \mathrm{kN}$ static load cell. The films were cut into strips of $10 \mathrm{~mm}$ wide and $100 \mathrm{~mm}$ long. Initial grip separation and cross-head speed were set at $100 \mathrm{~mm}$ and $50 \mathrm{~mm} \mathrm{~min}^{-1}$, respectively. TS and $\mathrm{E}$ was evaluated in five samples from each type of film.
2.5.2 Water vapor permeability (WVP). The WVP of films was determined gravimetrically following a modified ASTM E9680 standard method, adapted to edible materials by Mchugh et al. ${ }^{26}$ Circular glass cups with a diameter of $37 \mathrm{~mm}$ and a depth of $68 \mathrm{~mm}$ were applied. The circular film sample was sealed onto the cup mouth containing $6 \mathrm{ml}$ distilled water $(100 \% \mathrm{RH}$; $3.1671 \times 10^{3} \mathrm{~Pa}$ vapor pressure at $25^{\circ} \mathrm{C}$ ), stored at a desiccators at $25{ }^{\circ} \mathrm{C}$ and $0 \% \mathrm{RH}$ (0 Pa water vapor pressure) including silica gel. Then, the weight loss of the glass permeation cell was calculated every $2 \mathrm{~h}$ for $10 \mathrm{~h}$. WVP was calculated using the following equation:

$$
\mathrm{WVP}=\frac{\Delta m \times e}{\Delta t \times \Delta p \times A}
$$

where $\Delta m / \Delta t$ is the weight loss of moisture per unit of time $\left(\mathrm{g} \mathrm{s}^{-1}\right), A$ is the film area exposed to the moisture transfer $\left(1.08 \times 10^{-3} \mathrm{~m}^{2}\right), e$ is the film thickness $(\mathrm{m})$, and $\Delta P$ is the water vapor pressure difference across the two sides of the film specimen $(\mathrm{kPa})$. Three replicates for each film were carried out.

2.5.3 Opacity index. Opacity was determined according to Maran et al. $^{27}$ by measuring the film absorbance at $600 \mathrm{~nm}$ using a using a UV-1650 spectrophotometer (Model PC, Shimadzu, Kyoto, Japan). The film specimens were cut into a rectangle piece $(1 \mathrm{~cm} \times 4 \mathrm{~cm})$ and directly placed in a spectrophotometer test cell. Air was used as reference. The opacity of the films was determined by the following equation:

$$
\text { Opacity }=\frac{\mathrm{Abs}_{600}}{x}
$$

where $\mathrm{Abs}_{600}$ is the value of absorbance at $600 \mathrm{~nm}$ and $x$ is the film thickness (mm).

2.5.4 Color. Color was measured using a Konica Minolta CR-400 Chroma Meter (Konica Minolta Sensing, Inc., Osaka, Japan) under a standard white reflector plate, and Hunter values $\left(L^{*}, a^{*}\right.$ and $\left.b^{*}\right)$ were obtained. The Hunter $L^{*}, a^{*}$, and $b^{*}$ values for the standard plate were $L^{*}=97.25, a^{*}=-0.52$, and $b^{*}=$ 1.22 .

\subsubsection{Antimicrobial activity}

2.5.5.1 Microbial strains. Escherichia coli (ATCC 25922), Staphylococcus aureus (ATCC 29213), Lactobacillus plantarum (ATCC 4008) and Pseudomonas aeruginosa (ATCC 27853) were used in this study.

2.5.5.2 Determination of minimal inhibitory concentration (MIC) and minimal bactericidal concentration (MBC) of TML in an in vitro condition. The MIC and $\mathrm{MBC}$ of TML against four studied microorganisms (E. coli, $S$ aureus, $P$. aeruginosa and $L$. plantarum) were determined in vitro using broth microdilution method..$^{28-30}$ Serial dilutions of antimicrobial agents (3000; $1500 ; 1250 ; 1000 ; 750 ; 625 ; 500 ; 375 ; 312.5 ; 250 \mathrm{mg} \mathrm{l}^{-1}$ ) were prepared in sterile TSB for the bacteria ( $E$. coli, $S$ aureus, $P$. aeruginosa), and in sterile MRS for the bacteria (L. plantarum). A control tube without antimicrobial agents was inoculated to test microbial growth and another tube containing only broth medium was ensure no possible contaminations. MIC is defined as the lowest concentration $\left(\mathrm{mg} \mathrm{l}^{-1}\right)$ of TML at which the growth of the microorganism is prevented, and $\mathrm{MBC}$ is 
defined as the lowest concentration $\left(\mathrm{mg} \mathrm{l}^{-1}\right)$ of TML at which the incubated microorganism is killed.

2.5.5.3 Antimicrobial properties of the films. To determine the antimicrobial properties of the films, the agar diffusion method was used. The nutrient agar medium in Petri dish was inoculated with $100 \mu \mathrm{L} 10^{5}$ to $10^{6} \mathrm{cfu} \mathrm{ml}^{-1}$ bacteria. The prepared films were cut into $10 \mathrm{~mm}$ diameter discs using a holepuncher and then placed on inoculated agar. L. plantarum was incubated in MRS broth at $28{ }^{\circ} \mathrm{C}$ for 24 h. E. coli, S. aureus and $P$. aeruginosa were incubated in tryptic soy broth at $37^{\circ} \mathrm{C}$ for $24 \mathrm{~h}$. The diameter of the inhibition zone was measured in $\mathrm{mm}$ using a caliper. ${ }^{22}$

2.5.6 Total phenolic content assay. Total phenolic content (TPC) was determined by the Folin-Ciocalteu reagent method and using gallic acid equivalent (GAE) as a standard. The results were expressed as $\mathrm{mg}$ of GAE per grams of film. ${ }^{31}$

2.5.7 Antioxidant activity. The antioxidant activity of the films was determined using 2,2-diphenyl-1-picrylhydrazyl (DPPH) radicals scavenging assay. ${ }^{32}$ All films $(25 \mathrm{mg})$ were dissolved in $3 \mathrm{ml}$ distilled water, and then $3 \mathrm{ml}$ of the film extract solution were mixed with $1 \mathrm{ml}$ of $1 \mathrm{mM}$ methanolic solutions of DPPH and incubated at ambient temperature for $30 \mathrm{~min}$ in darkness. The absorbance measured at $517 \mathrm{~nm}$. The percentage of DPPH was calculated by using the following equation:

$\mathrm{DPPH}$ scavenging effect $(\%)=\frac{\mathrm{Abs}_{\mathrm{DPPH}}-\mathrm{Abs}_{\text {film extract }}}{\mathrm{Abs}_{\mathrm{DPPH}}} \times 100$

2.5.8 Fourier transform infrared (FTIR) spectra analysis. FTIR spectra of these films were obtained using a Perkin Elmer spectrometer (Spectrum two, Perkin Elmer, IL, USA). The FTIR spectra of these films were recorded from 4000 to $500 \mathrm{~cm}^{-1}$ at resolution of $1 \mathrm{~cm}^{-1}$.

2.5.9 Scanning electronic microscopy (SEM). Film surfaces morphology were examined using a scanning electron microscope (FE-SEM, S4800, Hitachi, Japan), and operated at a voltage of $1.0 \mathrm{kV}$. Prior to visualization, the specimens were gold coated to prevent charging under the electron beam.

\subsection{Statistical analysis}

All experimental designs were performed in triplicate and data were analyzed by variance (ANOVA) using SPSS (version 12.1, SPSS, Chicago, IL, USA). Values are expressed as means \pm SD. Statistical significance between means was determined using Duncan's multiple range tests and the significant difference between treatments set at the $95 \%$ confidence level.

\section{Results and discussion}

\subsection{Mechanical properties}

Fig. 1 shows stress-strain curves of films. Notably, film containing TML was more rigid than the control film. This behavior was possibly due to TML having low affinity toward water. Table 1 summarizes the results of incorporating TML in different proportions on the mechanical properties of modified PPI films. The incorporation of TML at low concentration $(0.5 \%$

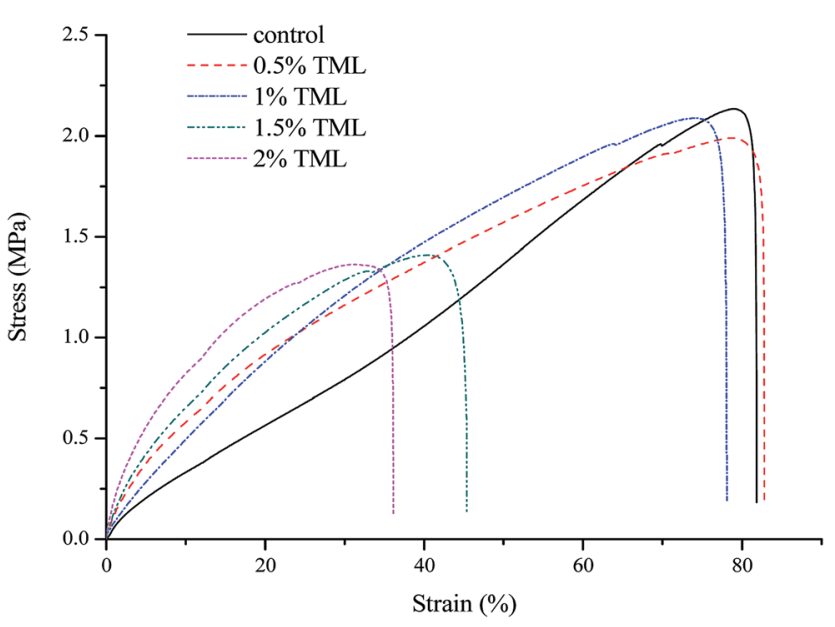

Fig. 1 Stress-strain curves of modified PPI films incorporated with different amounts of thymol (TML).

$\mathrm{w} / \mathrm{v}$ ) resulted in increased TS and E compared with the control $(p>0.05)$. However, TML incorporation above $1 \%$ concentration resulted in a significant decrease of the TS and $\mathrm{E}$ of the film $(p<$ 0.05). Since TML formed a non-miscible emulsified phase, the protein chains segregated to constitute a protein-rich phase. We suggested that the addition of a low concentration of TML to the modified PPI film matrix would favor protein-protein interactions. According to previous study, adding higher concentration of hydrophobic agents to a film may result in lower flexibility and resistance to fracture due to the structure with less mobility, ${ }^{33}$ which may explain why film incorporating TML above $1 \%$ concentration had decreased TS and E. Similar results were also obtained for whey edible protein films with added almond and walnut oils, ${ }^{34}$ and TML was added to novel nanobiocomposite films based on poly(lactic acid). ${ }^{35}$ The results showed the observed mechanical changes were not dramatic decreased, and that adding low content of TML did not interfere with the applicability of the developed films.

\subsection{Water vapour permeability (WVP)}

The addition of TML into modified PPI film led to lower WVP values than the control film, and a decreasing tendency of WVP with increasing TML concentration was also observed. This result may be explained by the hydrophobic nature of TML, which affects the hydrophilic/hydrophobic balance of the film. ${ }^{36}$ Similar results were found in PLA-based films containing TML, and chitosan films incorporated with carvacrol. ${ }^{37,38}$ However, other works found that the addition of essential oils caused no changes in WVP, ${ }^{39,40}$ or that the addition of essential oils improved WVP. ${ }^{36,41}$ Therefore, it cannot be assumed that the WVP values of edible films are reduced easily by adding hydrophobic constituents into the film matrix. Since the primary function of food packaging is to avoid or reduce moisture transfer between the surrounding atmosphere and the food, the WVP should be as low as possible. Our results indicated that modified PPI film with TML could potentially be used for food packaging by enhancing water resistance. 
Table 1 Mechanical properties, and water vapor permeability (WVP) properties of PPI modified films incorporated with different amounts of thymol (TML) $)^{a}$

\begin{tabular}{llll}
\hline TML $(\% \mathrm{w} / \mathrm{v})$ & Tensile strength $(\mathrm{MPa})$ & $E(\%)$ & $\left.\mathrm{WVP}^{(\mathrm{g} \mathrm{mm} \mathrm{kPa}} \mathrm{mm}^{-1} \mathrm{~m}^{-2}\right)$ \\
\hline 0 (control) & $2.17 \pm 0.04^{\mathrm{a}}$ & $82.80 \pm 2.76^{\mathrm{a}}$ & $2.10 \pm 0.10^{\mathrm{a}}$ \\
0.5 & $2.22 \pm 0.03^{\mathrm{a}}$ & $84.45 \pm 1.90^{\mathrm{a}}$ & $1.61 \pm 0.08^{\mathrm{b}}$ \\
1 & $2.17 \pm 0.03^{\mathrm{a}}$ & $78.91 \pm 1.81^{\mathrm{a}}$ & $1.48 \pm 0.06^{\mathrm{b}}$ \\
1.5 & $1.52 \pm 0.06^{\mathrm{b}}$ & $44.77 \pm 4.68^{\mathrm{b}}$ & $1.17 \pm 0.08^{\mathrm{c}}$ \\
2 & $1.26 \pm 0.16^{\mathrm{c}}$ & $37.72 \pm 3.07^{\mathrm{c}}$ & $1.15 \pm 0.08^{\mathrm{c}}$
\end{tabular}

${ }^{a}$ Values are given as mean \pm standard deviation. Different letters in the same column indicate significantly different $(p<0.05)$ when analyzed by Duncan's new multiple range test.

\subsection{Opacity and color parameters}

Color and opacity are important factors that influence consumers in buying a food product. The color and opacity parameters of each film are shown in Table 2. Compared to the control film, films incorporating TML were less transparent since the opacity increased. The opacity of the film samples significantly increased with increasing TML concentration $(p<$ 0.05). This finding is in agreement with Ramos et $a l^{42}$ It could be ascribed to the presence of polyphenols in the films. ${ }^{43}$

There was no significant difference among $L^{*}, a^{*}$ and $b^{*}$ values of the modified PPI films containing TML, except for the film containing $2 \%(\mathrm{w} / \mathrm{v})$ TML, which had a lower $L^{*}$ and higher $b^{*}$ value $(p<0.05)$, indicating that the film became yellowish and darker. These results suggested that adding low concentrations of TML did not influence the film color, but incorporating high concentrations of TML could change the color of the film. Similar tendencies in color have been reported that incorporating $3 \%(\mathrm{v} / \mathrm{v})$ ZEO in starch films decreased $L^{*}$ and increased $b^{*} \cdot{ }^{44}$ Although essential oils can affect the optical properties of film, they might have advantages as antioxidants due to the yellowish color protecting food products from light. ${ }^{39}$ According to data obtained in this study, modified PPI film added TML should be acceptable for use as see-through packaging.

\subsection{Antimicrobial activity of TML}

The antimicrobial activity of TML was assessed against four bacteria by determining the minimal inhibitory concentration (MIC) and minimal bactericidal concentration (MBC) values. As
Table 3 Minimal inhibition concentration (MIC) and minimal bactericidal concentration (MBC) of thymol (TML)

\begin{tabular}{lll}
\hline Bacteria & MIC $\left(\mathrm{mg} \mathrm{l}^{-1}\right)$ & MBC $\left(\mathrm{mg} \mathrm{l}^{-1}\right)$ \\
\hline E. coli & 500 & 3000 \\
S. aureus & 250 & 1000 \\
P. aeruginosa & 650 & 3000 \\
L. plantarum & 500 & 1250 \\
\hline
\end{tabular}

Table 3 shows, the MICs of TML toward Gram-positive bacteria (250-500 $\mathrm{mg} \mathrm{l}^{-1}$ ) were lower than those toward Gram-negative bacteria (500-650 $\mathrm{mg} \mathrm{l}^{-1}$ ). Regarding MBC, P. aeruginosa and $E$. coli needed the same concentration to kill bacterial cells (3000 $\mathrm{mg} \mathrm{l}^{-1}$ ), while L. plantarum and S. aureus needed 1250 and $1000 \mathrm{mg} \mathrm{l}^{-1}$ respectively. Therefore, TML was more effective against the Gram-positive L. plantarum and $S$. aureus than against the Gram-negative $E$. coli and $P$. aeruginosa in terms of both MIC and MBC values. This may be because the cell wall structures of these bacteria are different, the cell walls of Gram-negative bacteria include lipopolysaccharides, which may restrict active components from reaching the cytoplasmic membrane. ${ }^{\mathbf{4 5 , 4 6}}$ The results are different from those of Guarda et al. ${ }^{47}$ who reported TML had the same antimicrobial activity against $S$. aureus and $E$. coli $(\mathrm{MIC}=250 \mathrm{ppm})$. According to Atef et al., ${ }^{48}$ TML was more effective against $E$. coli than $P$. aeruginosa and $S$. aureus based on $\mathrm{MBC}$ value. These differences may be due to the use of different methods to obtain TML and/or differences in protocols of the antimicrobial measurements.

Table 2 Color value and opacity for PPI modified films incorporated with different amounts of thymol (TML) ${ }^{a}$

\begin{tabular}{lllll}
\hline & & Color & & \\
\cline { 3 - 5 } TML $(\% \mathrm{w} / \mathrm{v})$ & Opacity $\left(\mathrm{A} \mathrm{mm}^{-1}\right)$ & $L^{*}$ & $a^{*}$ & $b^{*}$ \\
\hline 0 (control) & $1.52 \pm 0.05^{\mathrm{d}}$ & $77.68 \pm 0.81^{\mathrm{a}}$ & $4.19 \pm 0.18^{\mathrm{ab}}$ & $2.79 \pm 0.82^{\mathrm{bc}}$ \\
0.5 & $2.76 \pm 0.08^{\mathrm{c}}$ & $81.48 \pm 1.31^{\mathrm{a}}$ & $2.79 \pm 0.07^{\mathrm{b}}$ & $19.08 \pm 0.69^{\mathrm{c}}$ \\
1 & $3.07 \pm 0.13^{\mathrm{b}}$ & $78.70 \pm 1.90^{\mathrm{a}}$ & $3.09 \pm 0.49^{\mathrm{b}}$ & $23.94 \pm 0.66^{\mathrm{b}}$ \\
1.5 & $3.11 \pm 0.03^{\mathrm{b}}$ & $79.07 \pm 3.41^{\mathrm{a}}$ & $3.07 \pm 1.30^{\mathrm{b}}$ & $22.64 \pm 2.81^{\mathrm{b}}$ \\
2 & $3.44 \pm 0.02^{\mathrm{a}}$ & $72.51 \pm 4.69^{\mathrm{b}}$ & $5.59 \pm 1.34^{\mathrm{a}}$ & $29.13 \pm 0.58^{\mathrm{a}}$
\end{tabular}

${ }^{a}$ Values are given as mean \pm standard deviation. Different letters in the same column indicate significantly different $(p<0.05)$ when analyzed by Duncan's new multiple range test. 


\subsection{Antimicrobial properties}

Inhibition zone diameters of modified PPI based edible film disks containing various concentrations of TML $(0,0.5,1,1.5$ and $2 \%$ ) against test bacteria are shown in Table 4 . No inhibition zone was observed for the control film (without TML). Adding TML into films led to inhibition of all test bacteria even at the minimum concentration $(0.5 \%)$ applied into the film formulation. As the concentration increased, the zones of inhibition increased significantly in a concentration-dependent manner $(p<0.05)$. Fig. 2 shows the inhibition zones obtained with modified PPI films containing 2\% TML against $S$. aureus, $L$. plantarum, E. coli and $P$. aeruginosa. At all concentrations assayed, $S$. aureus showed the largest inhibition zones $(p<0.05)$ with values between 22.23 and $32.62 \mathrm{~mm}$ (including the film disc), followed by $L$. plantarum and $E$. coli with statistically significant differences $(p<0.05)$ between them. $P$. aeruginosa was the most resistant bacterium $(p<0.05)$, with inhibition zones 13.01-19.55 $\mathrm{mm}$ (including the film disc). The results were in agreement with previous reports that Gram-positive bacteria are more sensitive than Gram-negative bacteria to

Table 4 Antibacterial activity expressed as the inhibition zone $(\mathrm{mm})$ of modified PPI films incorporate different amounts of thymol (TML) ${ }^{a}$

\begin{tabular}{|c|c|c|c|c|}
\hline TML $(\% \mathrm{w} / \mathrm{v})$ & \multicolumn{4}{|c|}{ Inhibition zone (mm) } \\
\hline 0.5 & $13.73 \pm 0.65^{\mathrm{c}}$ & $22.23 \pm 0.23^{\mathrm{c}}$ & $13.01 \pm 0.53^{\mathrm{c}}$ & $16.19 \pm 0.22^{\mathrm{d}}$ \\
\hline 1 & $16.93 \pm 0.49^{\mathrm{b}}$ & $22.48 \pm 0.54^{\mathrm{c}}$ & $16.55 \pm 0.24^{\mathrm{b}}$ & $16.85 \pm 0.27^{\mathrm{c}}$ \\
\hline 1.5 & $20.13 \pm 0.49^{\mathrm{a}}$ & $29.59 \pm 0.57^{b}$ & $19.55 \pm 0.09^{\mathrm{a}}$ & $19.56 \pm 0.20^{\mathrm{c}}$ \\
\hline
\end{tabular}

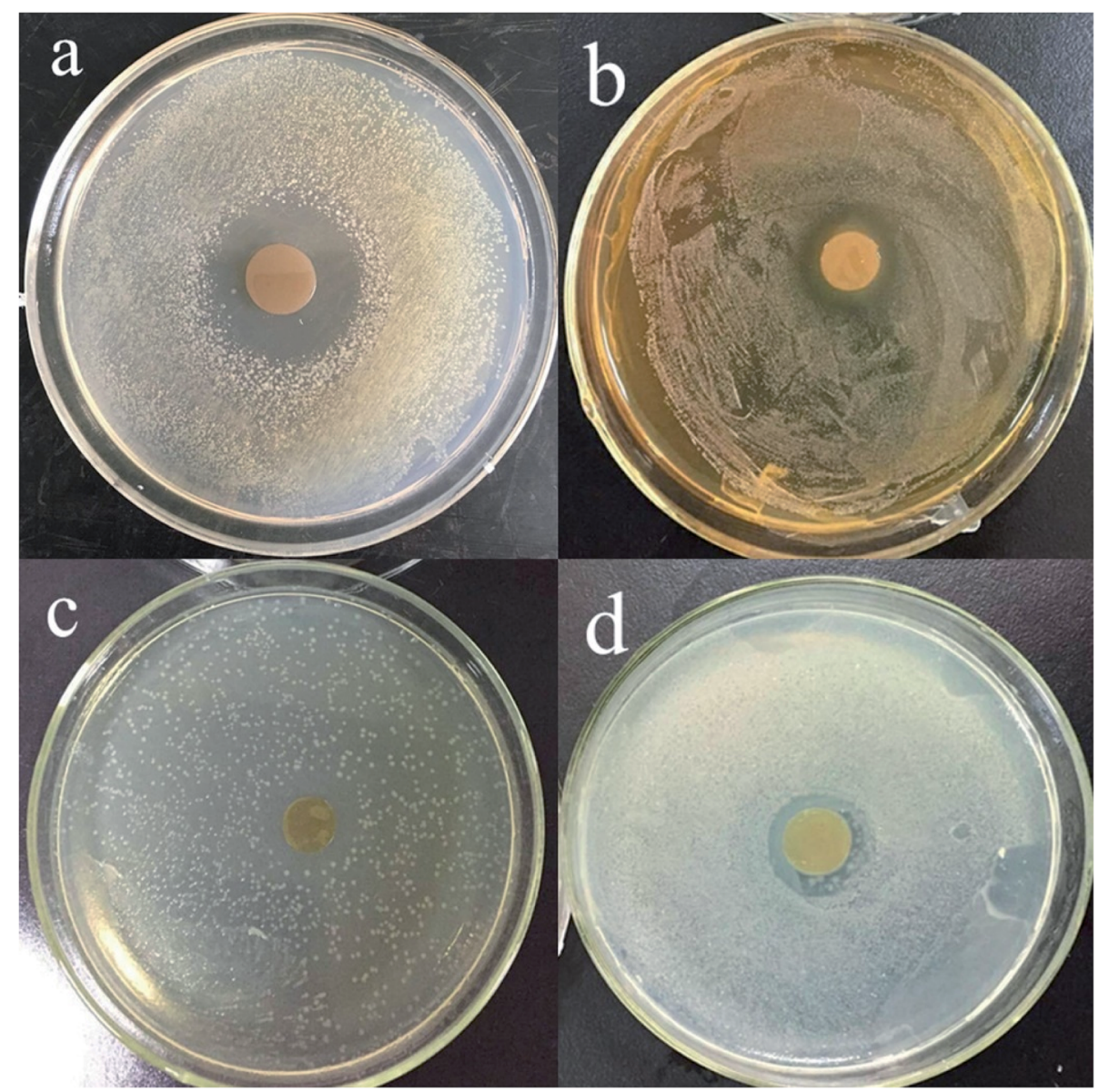

Fig. 2 Representative pictures of inhibitory zones of modified PPI films incorporated with $2 \%(\mathrm{w} / \mathrm{v})$ thymol (TML) against tested microorganisms: (a) S. aureus, (b) L. plantarum, (c) E. coli, and (d) P. aeruginosa. 
essential oils and their components. ${ }^{12,48}$ It was reported that pullulan films containing TML gave rise to their largest inhibition haloes for Gram-positive bacteria (B. subtilis and $S$. aureus) and their smallest inhibition haloes for Gram-negative bacteria (E. coli and $S$. enteritidis). ${ }^{49}$ It was also reported that polypropylene films containing TML were more effective against S. aureus than E. coli. ${ }^{\mathbf{5 0}}$

The mechanism of the inhibitory effect of TML on the growth of various microorganisms is not completely known, but several studies have shown that the antimicrobial activity of TML involves inner and outer membrane disruption, and interaction with intracellular targets and membrane proteins. The interactions affect cell membrane permeability, evidenced by cellular uptake of ethidium bromide, loss of membrane potential, ATP, leakage of potassium ions, and carboxyfluorescein. ${ }^{16,51,52}$

It should be also noted that the inhibitory effect of TML included in film matrices was lower than that of pure TML, which may due to partial loss of volatile compounds during film manufacturing. ${ }^{36}$ However, our results show that TML can be successfully immobilized in modified PPI films and consequently released, thereby inhibiting target microorganisms.

\subsection{Total phenolic content (TPC) and antioxidant activity}

The TPC and antioxidant activity values of modified PPI films are shown in Fig. 3 and 4. Phenolic compounds are suggested to be the most active antioxidant extracts from plants. ${ }^{53}$ The total phenolic content and antioxidant activity of some medicinal plant infusions were analyzed, which showed a significant linear correlation between total phenolic content and antioxidant activity. ${ }^{54,55}$

In the present study, total phenolic activity varied from 0.43 to $3.82 \mathrm{mg}$ gallic acid per $\mathrm{g}$ film, and antioxidant activity changed from 4.25 to $22.47 \%$. The results showed that TPC in the modified PPI films significantly increased $(p<0.05)$ with

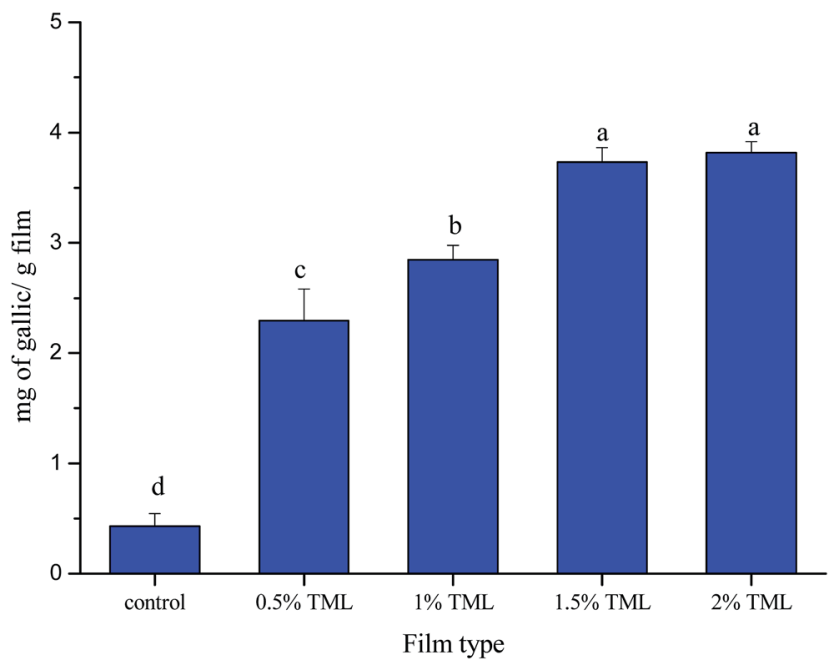

Fig. 3 Total phenolics contents of modified PPI films incorporated with different amounts of thymol (TML). Different letters indicate a statistically significant difference $(P<0.05)$.

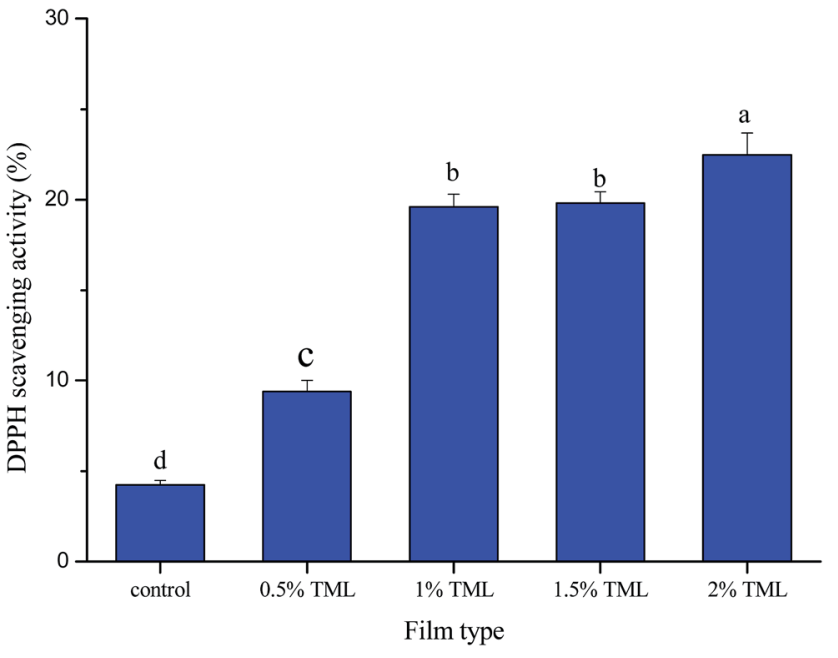

Fig. 4 DPPH scavenging activity of PPI modified films incorporated with different amounts of thymol $(T M L)$. Different letters indicate a statistically significant difference $(P<0.05)$.

increasing TML concentration. As expected, the antioxidant activity of the films increased progressively with addition of TML. The highest TPC and antioxidant activity was found in the film containing $2 \% \mathrm{TML}$, the values were 8.88 -times and 5.29times greater than those in the control film, respectively. Previous studies have also found that TML has antioxidant activity, and the addition of TML to film matrix conferred antioxidant ability on the film. ${ }^{56,57}$ The present study confirms those findings.

\subsection{Fourier transform infrared (FTIR) spectra analysis}

The FTIR spectra of modified PPI-based films with and without TML showed similar major peaks, but the amplitudes of the peaks varied depending on the amount of TML incorporated (Fig. 5). The absorption bands at $3650-3200 \mathrm{~cm}^{-1}$ and $2930 \mathrm{~cm}^{-1}$ correspond to the stretching vibration of free

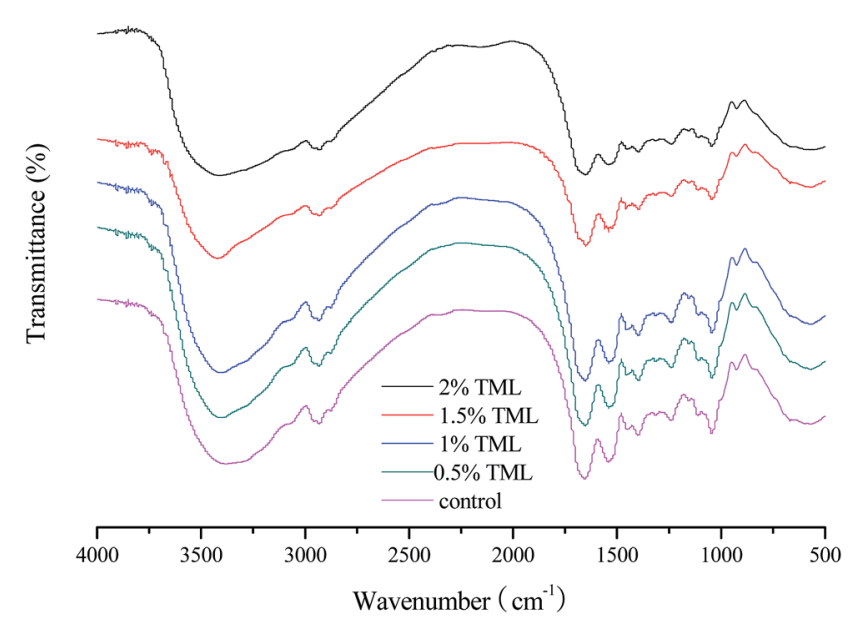

Fig. 5 FTIR spectra of modified PPI films incorporated with different amounts of thymol (TML). 
hydroxyl and the stretching vibration of $\mathrm{C}-\mathrm{H}$, respectively. The characteristic bands of the film at approximately 1654, 1542, and $1241 \mathrm{~cm}^{-1}$ are assigned to the amide-I $(\mathrm{C}=\mathrm{O}$ stretching $)$, amide-II ( $\mathrm{N}-\mathrm{H}$ bending) and amide-III $(\mathrm{N}-\mathrm{H}$ bending and $\mathrm{C}-\mathrm{N}$ stretching) bands, respectively. The band observed at $1044 \mathrm{~cm}^{-1}$ arises from an $-\mathrm{OH}$ group, mainly from glycerol added as a plasticizer. $^{58}$
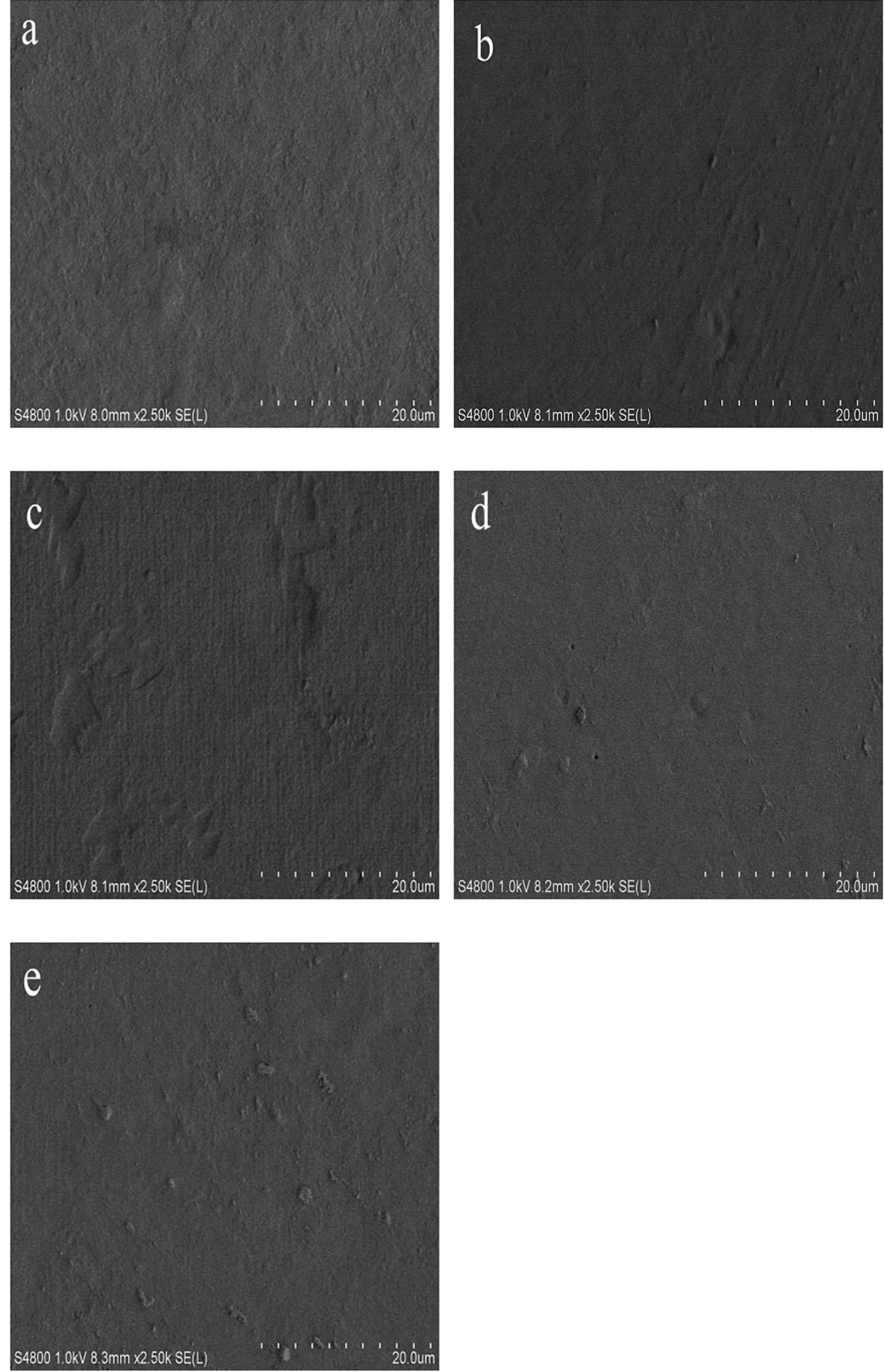

Fig. 6 Scanning electron micrographs of the surface of modified PPI films incorporated with different amounts of thymol (TML): (a) control, (b) $0.5 \% \mathrm{TML}$, (c) $1 \% \mathrm{TML}$, (d) $1.5 \% \mathrm{TML}$, (e) $2 \% \mathrm{TML}$ 
It can be seen from the FTIR spectra that as the amount of TML progressively added, the absorbance associated with $-\mathrm{OH}$ group (3650-3200 $\mathrm{cm}^{-1}$ ) and $\mathrm{N}-\mathrm{H}$ bending (amide-II at $1542 \mathrm{~cm}^{-1}$ and amide-III at $1241 \mathrm{~cm}^{-1}$ ) vibrations gradually decreased, which could be due to a particular arrangement in the films resulting from the interaction of TML with hydroxyl and amino groups in modified PPI. This result could explain to some degree the mechanical properties and WVP of the films with TML incorporated.

\subsection{Films morphology}

Fig. 6 shows micrographs of the film surfaces. The control film had a smooth and continuous structure. As compared to control film, the presence of TML made the film slightly rougher. Though TML caused discontinuities in the film matrix, the surface showed dense structure associated with TML as a hydrophobic agent. Similar results were observed for chitosan films with added cinnamon essential oil, and chitosan films with added carvacrol and grape seed extract. ${ }^{59,60}$ Pores can be seen in Fig. $5 d$, which might due to the evaporation of TML during dehydration. ${ }^{61}$ We postulate that the film microstructure could be related to the lower WVP of films containing TML compared with the control film.

\section{Conclusions}

The incorporation of thymol into modified peanut protein isolate matrix was successfully performed to obtain biodegradable films. Modification of PPI film by adding thymol (TML) significantly improved (i.e. lowered) water vapor permeability, and increased antioxidant and antimicrobial activity. Addition of a low concentration of TML did not affect the mechanical properties of the film or its color, although high concentrations of TML negatively affected film mechanical properties and made the films darker. Based on our results, modified peanut protein isolate films incorporating TML have the potential to be used in the food industry as antimicrobial and antioxidant packaging materials.

\section{Conflicts of interest}

There are no conflicts to declare.

\section{Acknowledgements}

This work was supported by the Liaoning Provincial Nature Science Foundation of China (2013020067).

\section{References}

1 M. A. Rojas-Graü, R. Soliva-Fortuny and O. Martín-Belloso, Trends Food Sci. Technol., 2009, 20, 438-447.

2 S. F. Hosseini, M. Rezaei, M. Zandi and F. Farahmandghavi, Ind. Crops Prod., 2015, 67, 403-413.

3 X. Li, N. Ji, C. Qiu, M. Xia, L. Xiong and Q. Sun, Ind. Crops Prod., 2015, 77, 565-574.
4 C. Na, Y. Fu and J. He, Food Hydrocolloids, 2007, 21, 11531162.

5 G. Su, J. Ren, Y. Bao, C. Cui and M. Zhao, Food Chem., 2011, 126, 1306-1311.

6 H. Wu, Q. Wang, T. Ma and J. Ren, Food Res. Int., 2009, 42, 343-348.

7 M. Wihodo and C. I. Moraru, J. Food Eng., 2013, 114, 292302.

8 M. P. Arrieta, M. A. Peltzer, J. López, M. D. C. Garrigós, A. J. M. Valente and A. Jiménez, J. Food Eng., 2014, 121, 94101.

9 X. Liu, Z. Liu, L. Wang, S. Zhang and H. Zhang, RSC Adv., 2017, 7, 13707-13713.

10 A. Valdés, A. C. Mellinas, M. Ramos, N. Burgos, A. Jiménez and M. C. Garrigós, RSC Adv., 2015, 5, 40324-40335.

11 M. Masoomi, M. Tavangar and S. M. R. Razavi, RSC Adv., 2015, 5, 79200-79206.

12 S. Burt, Int. J. Food Microbiol., 2004, 94, 223-253.

13 R. Chizzola, H. Michitsch and C. Franz, J. Agric. Food Chem., 2008, 56, 6897-6904.

14 K. Feng, P. Wen, H. Yang, N. Li, W. Y. Lou, M. H. Zong and H. Wu, RSC Adv., 2017, 7, 1572-1580.

15 P. S. Chavan and S. G. Tupe, Food Control, 2014, 46, 115-120. 16 R. J. W. Lambert, P. N. Skandamis, P. J. Coote and G. J. E. Nychas, J. Appl. Microbiol., 2001, 91, 453-462.

17 P. Suppakul, J. Miltz, K. Sonneveld and S. W. Bigger, J. Food Sci., 2003, 68, 408-420.

18 S. Koosehgol, M. Ebrahimianhosseinabadi, M. Alizadeh and A. Zamanian, Mater. Sci. Eng., C, 2017, 79, 66-75.

19 K. Boonruang, N. Kerddonfag, W. Chinsirikul, E. J. Mitcham and V. Chonhenchob, Food Control, 2017, 78, 85-93.

20 Z. Aytac, S. Ipek, E. Durgun, T. Tekinay and T. Uyar, Food Chem., 2017, 233, 117-124.

21 M. Ramos, A. Beltrán, M. Peltzer, A. J. M. Valente and M. D. C. Garrigós, LWT-Food Sci. Technol., 2014, 58, 470-477.

22 E. Zehra Karagöz, Y. Gökçe Polat, C. Betül Kodal and C. Kezban, Meat Sci., 2010, 86, 283-288.

23 T. Li, W. Hu, J. Li, X. Zhang, J. Zhu and X. Li, Food Control, 2012, 25, 101-106.

24 M. Moradi, H. Tajik, S. M. R. Rohani and A. Mahmoudian, LWT-Food Sci. Technol., 2016, 72, 37-43.

25 Y. Liu, G. Zhao, M. Zhao, J. Ren and B. Yang, Food Chem., 2012, 131, 901-906.

26 T. H. Mchugh, R. Avenabustillos and J. M. Krochta, J. Food Sci., 2006, 58, 899-903.

27 J. P. Maran, V. Sivakumar, R. Sridhar and K. Thirugnanasambandham, Carbohydr. Polym., 2013, 92, 1335.

28 M. Turgis, K. D. Vu, C. Dupont and M. Lacroix, Food Res. Int., 2012, 48, 696-702.

29 D. Dussault, K. D. Vu and M. Lacroix, Meat Sci., 2014, 96, 514-520.

30 S. Shankar, L. Jaiswal, S. Periasamy, K. S. Ham and J. W. Rhim, RSC Adv., 2016, 6, 67340-67352.

31 E. A. Ainsworth and K. M. Gillespie, Nat. Protoc., 2007, 2, 875-877.

32 S. Ubonrat and H. Brucer, Food Hydrocolloids, 2010, 24, 770775. 
33 S. N. L. Laura, V. MaríA, G. L. N. Chelo, C. Amparo and C. F. Maite, Food Hydrocolloids, 2009, 23, 2102-2109.

34 S. Galus and J. Kadzińska, Food Hydrocolloids, 2016, 52, 7886.

35 M. Ramos, A. Jiménez, M. Peltzer and M. C. Garrigós, Food Chem., 2014, 162, 149-155.

36 S. Benavides, R. Villalobos-Carvajal and J. E. Reyes, J. Food Eng., 2012, 110, 232-239.

37 M. Ramos, E. Fortunati, M. Peltzer, A. Jimenez, J. M. Kenny and M. C. Garrigós, Polym. Degrad. Stab., 2016, 132, 2-10.

38 M. A. López-Mata, S. Ruizcruz, N. P. Silva-Beltrán, J. J. Ornelaspaz, P. B. Zamudioflores and S. E. Burruelibarra, Molecules, 2013, 18, 13735.

39 P. Klangmuang and R. Sothornvit, Food Hydrocolloids, 2016, 61, 609-616.

40 L. Atarés, R. Pérezmasiá and A. Chiralt, J. Food Eng., 2011, 104, 649-656.

41 S. F. Hosseini, M. Rezaei, M. Zandi and F. Farahmandghavi, Ind. Crops Prod., 2015, 67, 403-413.

42 M. Ramos, E. Fortunati, M. Peltzer, A. Jimenez, J. M. Kenny and M. C. Garrigós, Polym. Degrad. Stab., 2016, 132, 2-10.

43 G. Yuan, H. Lv, B. Yang, X. Chen and H. Sun, Molecules, 2015, 20, 11034-11045.

44 M. Ghasemlou, N. Aliheidari, R. Fahmi, S. Shojaee-Aliabadi, B. Keshavarz, M. J. Cran and R. Khaksar, Carbohydr. Polym., 2013, 98, 1117-1126.

45 M. Vaara, Microbiol. Rev., 1992, 56, 395-411.

46 B. Ouattara, R. E. Simard, R. A. Holley, J. P. Piette and A. Bégin, Int. J. Food Microbiol., 1997, 37, 155.

47 A. Guarda, J. F. Rubilar, J. Miltz and M. J. Galotto, Int. J. Food Microbiol., 2011, 146, 144.
48 M. Atef, M. Rezaei and R. Behrooz, Food Hydrocolloids, 2015, 45, 150-157.

49 M. Gniewosz and A. Synowiec, Flavour Fragrance J., 2011, 26, 389-395.

50 M. Ramos, A. Jiménez, M. Peltzer and M. C. Garrigós, J. Food Eng., 2012, 109, 513-519.

51 J. Xu, F. Zhou, B. P. Ji, R. S. Pei and N. Xu, Lett. Appl. Microbiol., 2008, 47, 174.

52 B. J. Juven, J. Kanner, F. Schved and H. Weisslowicz, J. Appl. Bacteriol., 1994, 76, 626-631.

53 W. Bors, C. Michel and K. Stettmaier, Methods Enzymol., 2001, 335, 166.

54 Y. M. Pan, K. Wang, S. Huang, H. S. Wang, X. M. Mu, C. H. He, X. W. Ji, J. Zhang and F. J. Huang, Food Chem., 2008, 106, 1264-1270.

55 C. C. Huang, H. F. Wang, C. H. Chen, Y. J. Chen and K. H. Yih, J. Cosmet. Sci., 2011, 62, 393.

56 G. Kavoosi, S. M. Dadfar and A. M. Purfard, J. Food Sci., 2013, 78, E244.

57 M. Davoodi, G. Kavoosi and R. Shakeri, Int. J. Biol. Macromol., 2017, 104, 173-179.

58 M. S. Hoque, S. Benjakul and T. Prodpran, J. Food Eng., 2010, 96, 66-73.

59 O. Seyedmahdi, R. Masoud, R. Seyedhadi and H. Seyedmohamadhashem, J. Biotechnol., 2010, 122, 161166.

60 J. F. Rubilar, C. Rms, H. D. Silva, A. A. Vicente, I. Khmelinskii and M. C. Vieira, J. Food Eng., 2013, 115, 466-474.

61 M. Jouki, S. A. Mortazavi, F. T. Yazdi and A. Koocheki, Carbohydr. Polym., 2014, 99, 537-546. 